\title{
RATING OF THE CUSTOMER SERVICE QUALITY AT COOPERATIVE BANKS IN MYSTERY SHOPPER STUDY
}

\author{
Marcin Idzik, $\mathrm{PhD}^{1}$ \\ Faculty of Economic Sciences, Warsaw University of Life Science - SGGW
}

\begin{abstract}
The objective of this paper is to evaluate the customer service quality at the cooperative banks in Poland and to test the extent of the customer oriented approach of selling banking services based on the relational model. The customer service level at the cooperative banks was evaluated as low in comparison with the results achieved by the commercial banks. The principles of the relational model and the customer-oriented sales model were fulfilled in $36 \%$. The analysis of the needs, using the feedback about the customer, the customer commitment and the effective sales were the least implemented. The highest level of implementation concerned the principles of comfortable customer service, the greeting and presentation of the offer. The selling efficiency is highly correlated with upholding the principles of a customer-oriented sales model. The study used the Mystery Shopper method.
\end{abstract}

Keywords: satisfaction, sales, trust

JEL codes: G41, M31, M37, M52; E71

\section{INTRODUCTION}

The necessity to perfect the customer service and utilize the feedback information received from the customers constitutes the basis for building the market advantage. In the banking services, the customer satisfaction mainly depends on the preparations and the social skills of the personnel because the customers buy good mood together with the product. In the opinion of the Chairman of the Polish Banking Association 'last year recorded a clear improvement as regards the customer service quality and the satisfaction with the daily use of the banking services. The NPS index (net promoter score), which informs about the number of customers who are ready to recommend the services of their bank, was above zero as regards the whole banking sector, and it improved by as many as 16 points within a year' (Rudke, 2018). From the Mystery Shopper study we can conclude that on average the banks in Poland fulfil $63 \%$ of the customers' expectations. However, the diversification of the ratings of satisfaction with the banking services differs: Nest Bank fulfils only $33 \%$ and the cooperative banks $-36 \%$ of the customers' demands. These are the worst results on the market. On the other hand, mBank fulfilled $91 \%$ of the customers' expectations as regards the customer service at the bank branches, Eurobank $-87 \%$, Getinbank - 84\%, and Millennium Bank $-81 \%$. These are the best results on the market (Piotrowicz and Machała, 2017). These results justify posing the question about the reasons for such low results of the cooperative bank which is promoted as a

${ }^{1}$ Corresponding author: Nowoursynowska 166,02-787 Warsaw, Poland, marcin_idzik@sggw.pl, +4822 5934110 
relational bank, a bank that are close to its customers and which understands and knows them. The answer to this question is even more important because $68 \%$ of the customers leave this bank and switch to the competitors because of the poor level of the customer service. $14 \%$ leave on account of the poor product quality, $9 \%$ because of the changes in the prices and the rest for the other reasons (Tomaszewicz, 2010). This opinion is justified by Barlow and Maul (2000) in one of the first research works on emotional values in the customer service process. This is a consequence of the customers' expectations to fulfil their functional and emotional needs. In the evaluation of Piotrowicz and Machała (2017), what was perceived as a 'wow' effect still a few years ago, nowadays is a sine qua non condition. The customers expect the bank personnel to present an offer in a comprehensive, exhaustive and relevant way. Moreover, being well-versed and competent in the offer is not enough. Knowing the customer, his/her style of using the financial services or lifestyle are of key importance. The objective of this paper is to answer the following questions: What is the level of the customer service quality at the branches of Bank Spółdzielczy? What is the extent of applying the principles of a customer oriented model of selling banking services based on a relational model? What is the banks' extent of utilization of the feedback information from the customers in the customer service process?

\section{QUALITY OF THE BANKING PRODUCT}

The components of the customer service quality are an integral part of creating a banking product in the banking services (Idzik and Gutkowska, 2014). This approach is only partially in agreement with the overall definition of quality proposed in the PN-EN ISO 9000:2006 norm, according to which quality is a stage where a set of product qualities meet specific customer demands (Prussak, 2003; Luning, Marcelis and Jongen, 2005; PN-EN ISO 9000:2009). From the bank's point of view, quality is the product's ability to fulfill the business objectives defined by such parameters as profitability and competitiveness (Karaszewski, 2005). Quality from the customer's point of view are product parameters and the customer service standards connected with the product (Prussak, 2003) which include: (i) the product core with its elementary functional benefits; (ii) the actual product that fulfils the necessary minimum of the buyer's expectations (price, quality, style, brand); and (iii) the enhanced product that includes additional benefits. Such an approach to the evaluation of the product quality can be described as technical. In the case of a banking product, the consumer definition of product quality considerably exceeds the technical parameters included in the offer (Idzik and Gutkowska, 2014). When defining a high quality banking product, the consumers most frequently provide adjectives which go considerably beyond the actual product as well as the enhanced product. A high quality banking product is transparent, comprehensive, offered according to the easy-to-follow rules, and in an honest and reliable manner. The consumers expect the bank personnel to understand their needs, respect and the serious treatment, and they assume that these expectations will be exemplified particularly in a banking product. This consumer definition of a high quality banking product indicates that it is necessary to change the scope of the definition of a banking product by ascribing human traits to the technical parameters of the products. In this original approach, the core product includes: fulfilling the elementary customer needs by the correct and safe provision of the services of the bank. The enhanced product means availability, price parameters, free-of-charge ATMs, reimbursement of a part of the costs, a network of bank branches, Internet and mobile banking, etc. Another stage in the banking product structure employs understanding the customer needs. This is expressed in the tailoring to the needs, consulting services, and assistance in making a decision. The highest level of the components creating a banking product include respect, and within it: keeping promises, empathy, altruism, long-lasting rules of cooperation and veracity (Idzik and Gutkowska, 2014). In the case of the sales service at a bank Tomaszewicz (2010) singles out four stages of building an intangible part of the product. Stage 1 - evoking overall trust includes first impression conveyed by the body language, tone of voice and the used expressions. Stage 2 - identification of the needs. Stage 3 - presentation of the offer and 
stage 4 - closing. A different concept was presented by Machała (2015) which singled out: partner-like treatment; commitment and dynamics; understanding the customer's problem; tailoring the offer to the needs. When these factors are fulfilled, we can enter the relational stage where an emotional bond is formed based on mutual understanding which is described in more detail by Kyzirdis (1996) and Czuba and Skurzyński (2003). However in their next concept, Piotrowicz and Machała $(2015,2017)$ already revised their current approach and proposed 7 areas that created intangible quality of the banking product: greeting, identification of the needs, presentation of the offer, sales process and commitment, closing the meeting, atmosphere of the conversation and the customer service comfort. The mentioned areas constitute the main axis for building the standards of retail customer service at the banks in Poland, and not upholding them is the elementary threat to the quality of the banking services in Poland (Machała, 2014, 2015).

\section{MATERIALS AND METHODS}

The customer service quality studies were conducted using the Mystery Shopping method. The Mystery Shopping study enables one to control the quality of the customer service (Churchill, 2002) and combines the elements of the quantitative and qualitative surveys (Maison and Noga-Bogomilski, 2007). The Mystery Shopping study involves observation of the front-line personnel in their natural conditions by a trained auditor (Milic-Czerniak, 2005). The Mystery Shopping study can be describe by three main features of the conducted observation (Meder, 2005): (i) the observation is inconspicuous, the sales assistant does not know that the customer is the Mystery Shopper; (ii) the observation is monitored - the auditor follows a specific script which should concentrate on certain elements of the customer service; (iii) it is standardized - the Mystery Shopper pays attention to specific aspects and after the survey, he/she fills out a questionnaire (Rutkowski, 2007). The results of the surveys conducted using the Mystery Shopping method in the first quarter of 2017 constituted the source of empirical data for the conducted analy- sis. The research included 33 branches of cooperative banks out of which 13 were members of BPS, 13 were members of SGB, 3 banks were a part of Krakowski Bank Spółdzielczy and 4 were unaffiliated banks. The visits to the bank branches were of an informational character as well as of a transactional character. At each of the studied bank branches, the auditors opened current accounts (ROR), activated channels for electronic banking if such were available, contacted the bank by phone, by E-mail or by a contact form on the bank's website. The research employed the measure of assessment of the customer service quality commonly used by the banks in Poland to create and verify the standards of the customer service quality at the bank branches (cf. Piotrowicz and Machała, 2015). The main assessed areas were: greeting, identification of the needs, the presentation of the offer, the sales process and commitment, closing the meeting, the atmosphere of the conversation and the comfort of the customer service. Each area was assessed on several detailed aspects.

\section{RESULTS AND DISCUSSION}

Treating quality as a gap between the expectations and the customer experiences serves as a starting point to improve quality. The assessment of the gap that divides a given bank from the competitive banks in terms of the customer service quality provided at the bank branches also plays a similar role. The cooperative banks achieve much lower scores of the customer service quality in comparison with the commercial banks (Fig. 1). In the ranking of the customer service quality in the bank branches of 19 banks, the cooperative banks take the penultimate position with the result of fulfilling only $36 \%$ of the customers' expectations (Piotrowicz and Machała, 2017). Only Nest Bank scored lower (33\%). In comparison with $91 \%$ achieved by mBank, the customer service quality leader, the cooperative banks are 55 p.p. behind.

The overall assessment of the customer service quality is an aggregated measure which includes: comfort of the customer service, greeting, presentation of the offer, closing the meeting, atmosphere of the conversation, identification of the needs as well as the sales and commitment (Fig. 2). 
Proceedings of the 2018 International Scientific Conference 'Economic Sciences for Agribusiness and Rural Economy' No 1, Warsaw, 7-8 June 2018, pp. 351-357

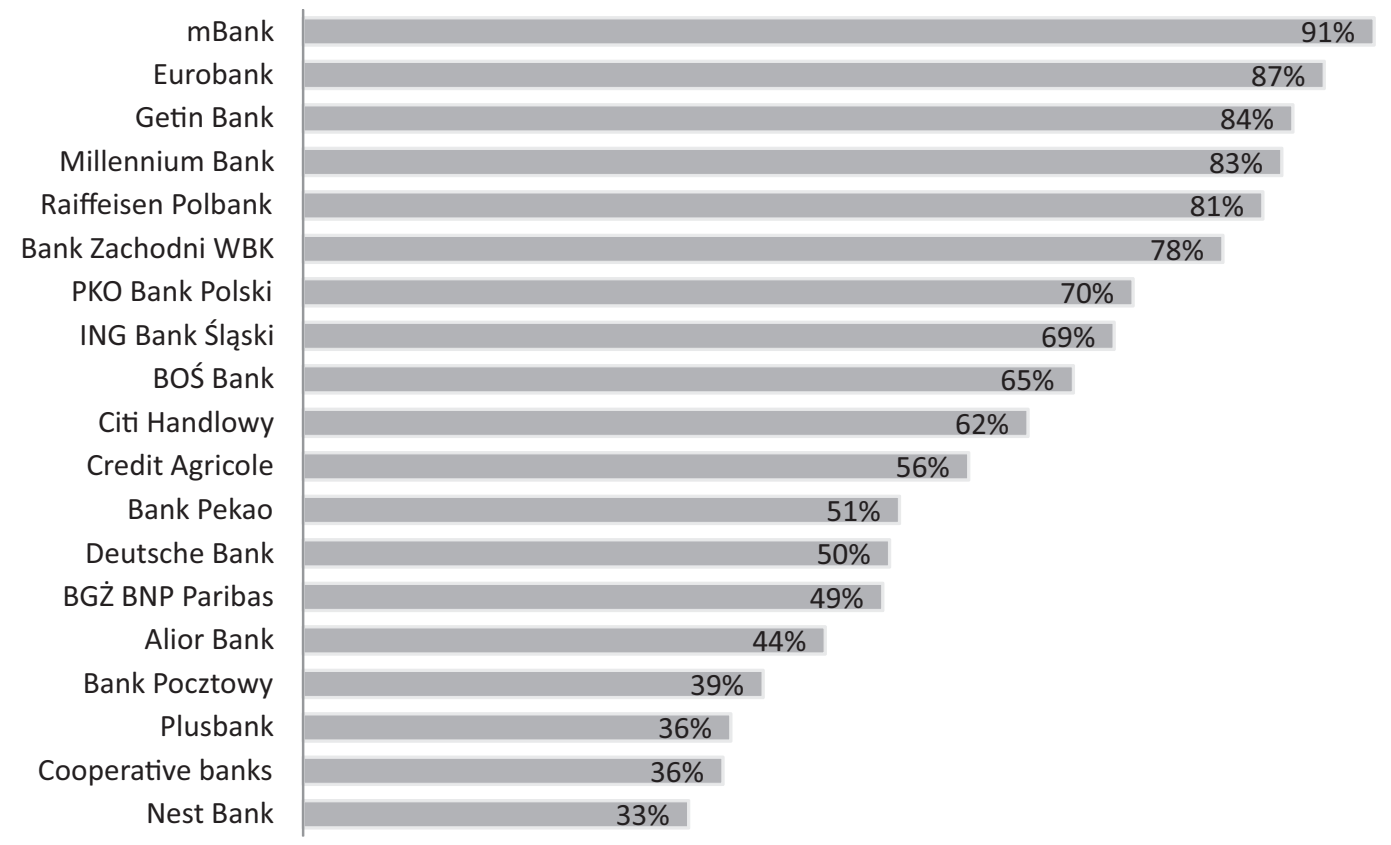

Figure 1. Rating of the customer service quality in banks in Poland

Source: own research on the basis of Piotrowicz and Machała (2017).

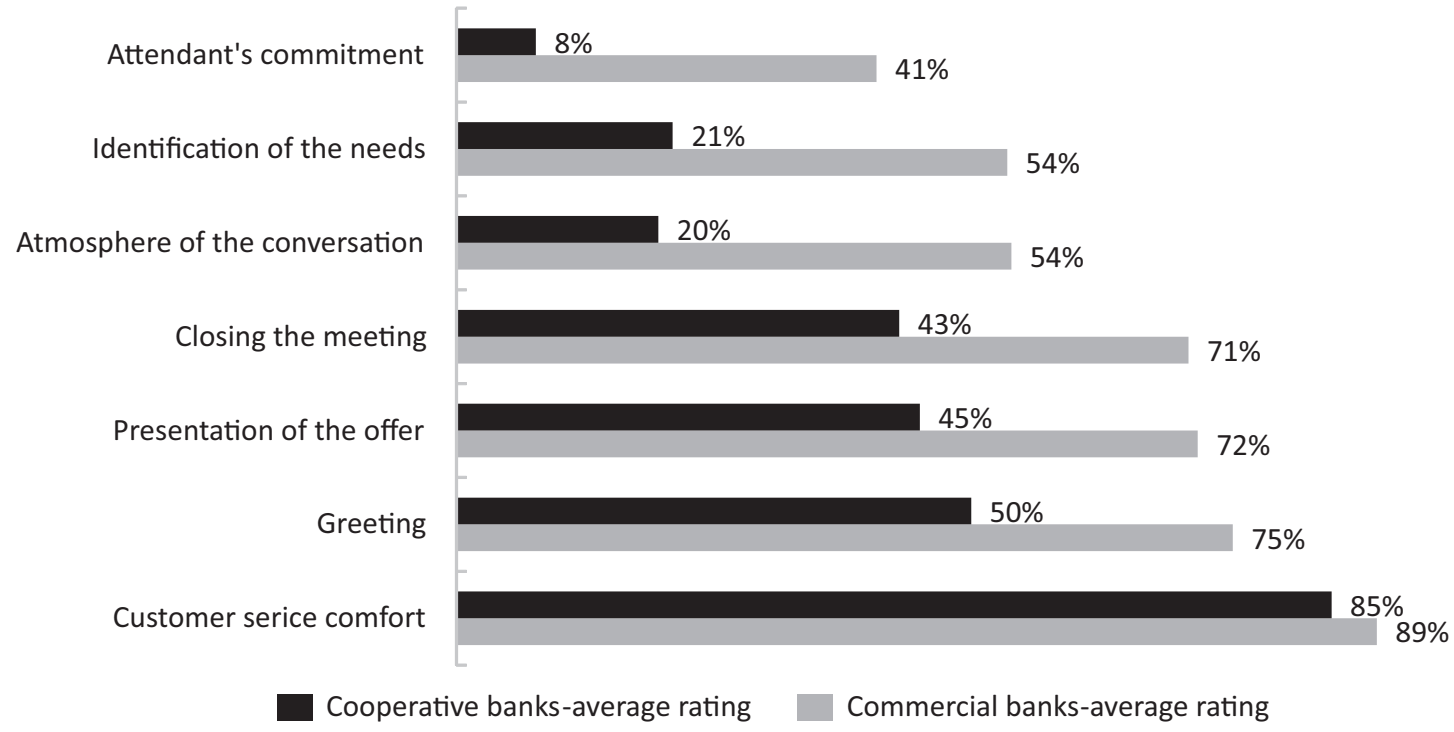

Figure 2. Properly fulfilled standards of the customer service quality at the cooperative and commercial banks Source: own research on the basis of Piotrowicz and Machała (2017).

Despite the fact that the cooperative banks declare a relational customer service model which centres around the familiarity with the customer and understanding his/her needs, in reality the assessment of this area is low (Fig. 2). The identification of the customer needs is fulfilled barely by $21 \%$, and the personnel commitment and the real willingness to address the customers' needs are fulfilled only by $8 \%$ in comparison with the real-life customers' demands in this regard. In the case of presentation of the of- 
fer, greeting or closing the meeting, the cooperative banks fulfil almost half of the standards for these areas of the customer service at the bank branches. The only area that scored relatively high and did not differ much from the scores of the commercial banks was the comfort of the customer service which reached $85 \%$. In comparison with the average market score among the commercial banks, the cooperative banks scored lower at the bank branches in all areas of the customer service quality. The gap in comparison with the market average is $33 \mathrm{pp}$ as regards personnel commitment, 33 p.p. -identification of the needs, 34 p.p. - atmosphere of the conversation, 28 p.p. closing the meeting, 27 p.p. - presentation of the offer, 25 p.p. - greeting, and 4 p.p. - comfort of the customer service. From several to a-dozen-or-so detailed aspects are used to measure the customer service quality at the bank branches in each of the areas. Here are some of them.

In the case of the cooperative banks, the first meeting with a customer attendant does not provide a good basis for building relations. In $22 \%$ of the cases, the attendant gave the impression as if the customer was bothering him/her, in $65 \%$ of the cases the attendant was polite, but did not go beyond normal courtesy, and in barely $13 \%$ of the cases the attendant was really happy to see the customer. This result is four times lower than among the commercial banks (Fig. 3 ). In the evaluation of Tomaszewicz (2010), it is this stage that determines whether the attendant can win the customer's trust or not ( $40 \%$ of the cases). In the opinion of Machała (2015), the identification of the needs is the key stage in the assessment of the quality of the sales customer service at the banks. During the sales customer service at the commercial banks in Poland, $40 \%$ of the personnel do not identify the customers' needs at all, or the posed questions do not allow for identification of the needs anyway. However, $60 \%$ of the customer service attendants at the commercial banks identify sufficiently the customers' needs. At the cooperative banks, barely $8 \%$ of the attendants carry out an effective identification of the needs. $92 \%$ do not identify the customers' needs at all or the questions they ask are insufficient for this purpose. In the opinion of Machała (2015), the openended questions which begin with 'How...' or 'In what way...' are very helpful during the stage of the identification of the needs. In the case of $70 \%$ of the bank branches in Poland on average, the personnel ask customers open-ended questions, but in the case of the cooperative banks, only $26 \%$ of the attendants pose such questions during the sales meeting. The sales process may have different dynamics and the attendants' commitment by one-fifth is a determinant for the final sales results.

Taking into consideration the average results for the commercial banks in Poland, $18 \%$ of the customer service attendants were not committed at all and wanted to present the offer as quickly as possible and to finish serving the customer; however, in the case of the cooperative banks, this number was $52 \%$. The attendants who are committed to the customer service at commercial banks constitute $46 \%$ and at cooperative banks - barely 5\% (Fig. 4).

In response to the customers' needs the attendants should present a customized offer which in many cases includes additional products. On average in Poland in $71 \%$ of the branches of the commercial

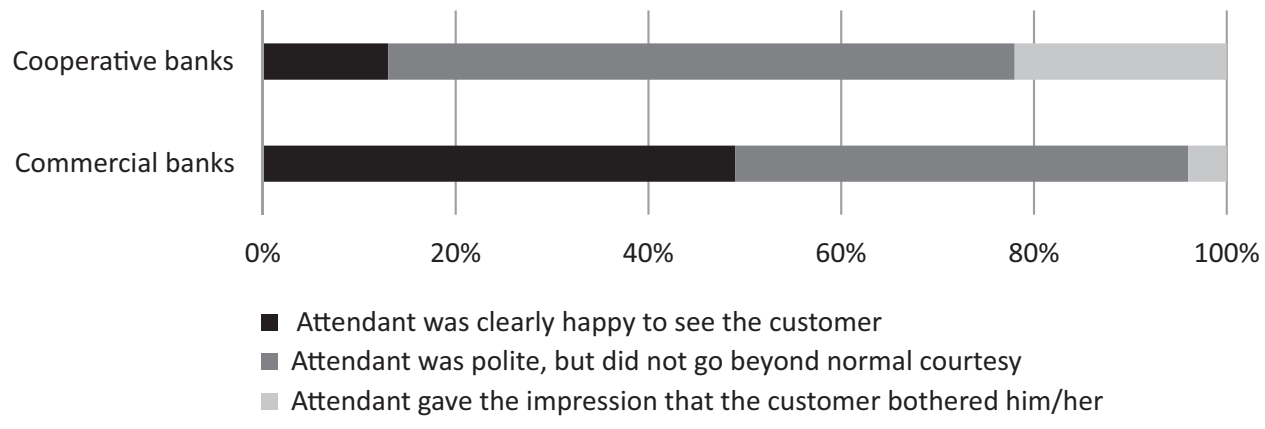

Figure 3. Bank attendants' behaviour when greeting the customer Source: own research. 


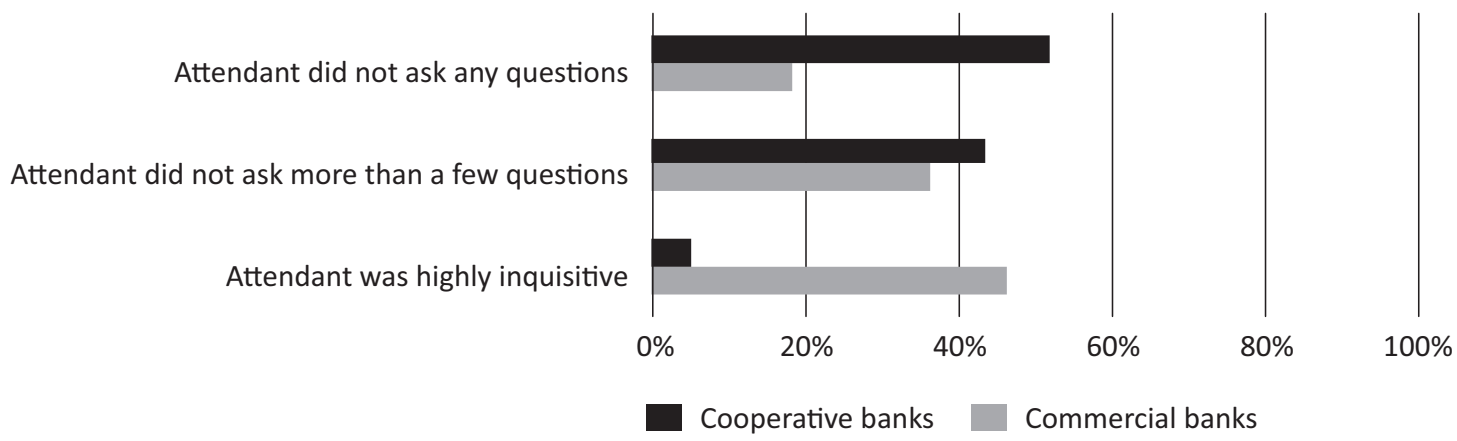

Figure 4. Attendants' commitment to the customer service

Source: own research.

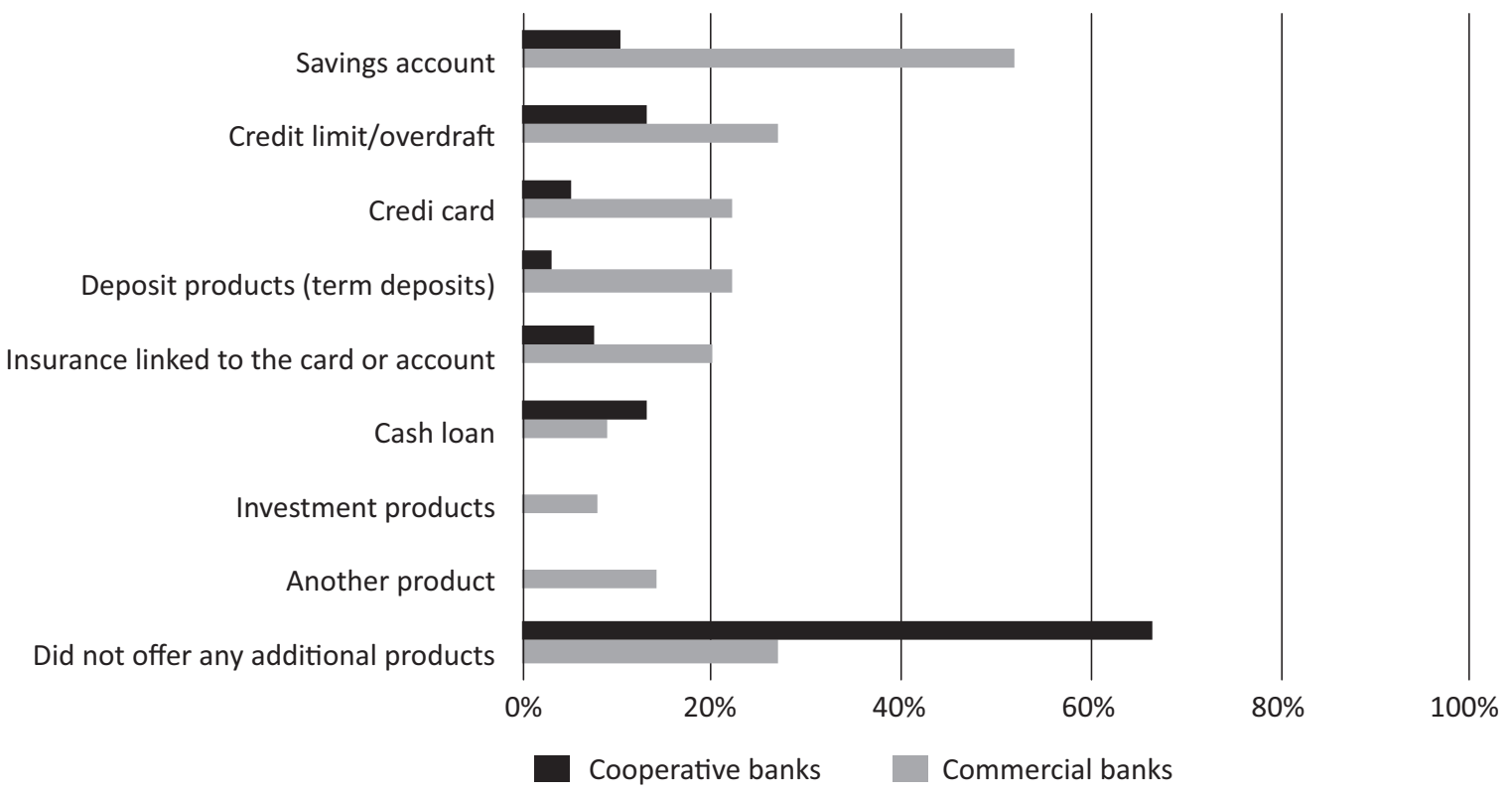

Figure 5. The scope of cross-selling used by the bank attendants when presenting the offer of a ROR current account

Source: own research.

banks, the attendants undertake actions to tailor the offer to the customers' needs. In the case of the cooperative banks, $26 \%$ attempt to tailor the offer. The scope of the offered additional products (Fig. 5) as well as the customers' inclination to buy the product are the direct results of tailoring the offer. In the case of the cooperative banks, $66 \%$ of the customer service attendants during the sales talk do not propose any additional products apart from the one the customer asked about. At the commercial banks this figure stands at $27 \%$.

\section{CONCLUSIONS}

The presented results can be a clue for the future model of the direct customer service at the banks. The level of the customer service at the cooperative banks lingers behind the standards employed at the commercial banks. The after-sales effectiveness of the cooperative banks' attendants is twice as low in comparison with the commercial banks. The cooperative banks practice the customer-oriented model of selling services to a limited extent. Getting infor- 
mation about the customers as well as using this information in the customer service process, tailoring the offer and building relations with the customer are on a very low level. Selling the financial services is to provide a certain combination of elements such as: knowledge, patience towards the customer, politeness, help and professional qualifications in fulfilling the customers' needs. All these elements should occur simultaneously. Moreover, the customer-oriented approach will require the fulfilment of several necessary conditions: determination and commitment of the management, efficient internal communication at the bank, strong middle management and having the Customer Experience Management program.

\section{REFERENCES}

1. Churchill, G. (2002). Badania marketingowe. Podstawy metodologiczne [Marketing research. Methodological basis]. Wydawnictwo Naukowe PWN, Warszawa.

2. Czuba, T., Skurzyński, M. (2003). Badania tajemniczy klient a badania satysfakcji [Mystery client surveys and satisfaction studies]. In: Mazurek-Łopacińska, K. (ed.) Badania marketingowe. Metody, tendencje, zastosowanie [Marketing research. Methods, trends, application]. Wrocław, pp. 255-259.

3. Idzik, M., Gutkowska, A. (2014). Czy klientów stać na dobry produkt? [Can customers afford a good product?]. In: Materiały konferencyjne. TNS Polska, Warszawa.

4. Karaszewski, R. (2005). Zarządzanie jakością. Koncepcje, metody i narzędzia stosowane przez liderów światowego biznesu [Quality management. Concepts, methods and tools used by global business leaders]. Dom Organizatora, Toruń.

5. Kyzirdis, P. (1996). Sales Management: Re-engineering the Sales Force for Relationship Marketing. In: European Society for Opinion and Marketing Research Symposium, Amsterdam, p. 52.
6. Luning, P.A., Marcelis, W.J., Jongen, W.M.F. (2005). Zarządzanie jakością żywności ujęcie technologicznomenadżerskie [Food quality management - technological and managerial approach]. WNT, Warszawa.

7. Machała, P. (2014). Zagrożenia, dla jakości usług bankowych [Threats for the quality of banking services]. TNS Polska, Warszawa.

8. Machała, P. (2015). I żyli długo i szczęśliwie...? [And they lived happily ever after...?]. In: XV Konferencja Finansowa TNS Polska, Warszawa, 21.05.2015 [manuscript].

9. Maison, D., Noga-Bogomilski, A. (2007). Badania marketingowe. Od teorii do praktyki [Marketing research. From theory to practice]. Gdańskie Wydawnictwo Psychologiczne, Gdańsk.

10. Meder, M. (2005). Zastosowanie metody Mystery Shopping w bankowości detalicznej [Application of the Mystery Shopping method in retail banking]. Marketing i Rynek, 5, 14.

11. Milic-Czerniak, R. (2005). Marketingowe badania bezpośrednie - zastosowanie [Direct marketing research - application]. Difin, IFIN, Warszawa.

12. Piotrowicz, H., Machała, P. (2015). Jakość na bank [Quality for the bank]. TNS Polska, Warszawa.

13. Piotrowicz, H., Machała, P. (2017). Złoty Bank 2017 [Golden Bank 2017]. Puls Biznesu. Special Issue of 21-23.04.2017.

14. PN-EN ISO 9001:2009. Systemy zarządzania jakością. Wymagania [Quality management systems. Requirements].

15. Prussak, W. (2003). Zarządzanie jakością. Wybrane elementy [Quality management. Selected elements]. Wydawnictwo Politechniki Poznańskiej, Poznań.

16. Rudke, M. (2018). Wysokie zaufanie do banków [High trust in banks]. Retrieved from: http://www.rp.pl/Banki/304249946-Wysokie-zaufanie-do-bankow.html [Accessed 14.05.2018].

17. Rutkowski, P. (2007). Kulisy Mystery Shopping [Backstage Mystery Shopping]. Marketing w Praktyce, 4.

18. Tomaszewicz, D. (2010). Sprzedaż i profesjonalna obsługa klienta [Sales and professional customer service]. Centrum Innowacji i Transferu Technologii UWM, O1sztyn. 